DOI: https://doi.org/10.24127/ajpm.v8i2.2118

\title{
KEMAMPUAN BERPIKIR KREATIF MATEMATIS SISWA SMP DALAM MENYELESAIKAN SOAL PEMECAHAN MASALAH DITINJAU DARI ADVERSITY QUOTIENT TIPE CLIMBER
}

\author{
Ratni Purwasih \\ Pendidikan Matematika, IKIP Siliwangi \\ E-mail: $\quad$ ratnipurwasih61@gmail.com
}

Received 11 July 2019; Received in revised form 30 October 2019; Accepted 6 November 2019

\begin{abstract}
Abstrak
Kemampuan berpikir kreatif merupakan kemampuan siswa untuk menemukan jalan penyelesaian yang tidak biasa, unik, dan belum pernah ditemukan oleh orang lain. Pengembangan konsep berpikir kreatif matematis dapat membuat siswa putus asa dan menyerah, sehingga dibutuhkan sebuah kemampuan lain agar siswa mampu bertahan dan mampu mengubah kesulitan-kesulitan yang ditemui menjadi peluang untuk dirinya lebih maju. Kemampuan yang dimiliki seseorang dalam mengamati kesulitan dan mengolah kesulitan tersebut dengan kecerdasan yang dimiliki sehingga menjadi sebuah tantangan untuk diselesaikan dikenal dengan Adversity Quotient (AQ). AQ terdiri dari 3 tipe, yaitu climber, camper, dan quitter. Penelitian ini merupakan penelitian deskriptif kualitatif. Penelitian ini bermaksud untuk mengetahui bagaimana tingkat kemampuan berpikir kreatif matematis dalam menyelesaikan soal kubus dan balok di tinjau dari Adversity Quotient tipe Climber. Penelitian dilaksanakan pada semester genap tahun pelajaran 2019/2020 di SMP Negeri 2 Ngamprah, kelas VIII yang berjumlah 31 siswa dan subjek dalam penelitian ini adalah 2 siswa. Metode pengumpulan data yang digunakan dalam penelitian ini meliputi: 1) tes yang digunakan untuk mengetahui kemampuan siswa dalam berpikir kreatif matematis; 2) wawancara yang berdasarkan tugas. Hasil penelitian menunjukkan bahwa siswa climber melakukan proses berpikir asimilasi pada tahap memahami masalah, menyusun rencana penyelesaian, menyelesaikan masalah sesuai perencanaan, dan memeriksa kembali hasil yang telah diperoleh dan memiliki kemampuan untuk mengerjakan soal-soal berpikir kreatif pada indikator fluency, felexibility.
\end{abstract}

Kata kunci: Adversity Quotient climber; kemampuan berpikir kreatif; pemecahan masalah.

\begin{abstract}
The ability to think creatively is the ability of students to find ways of solving that are unusual, unique, and have never been found by others. The development of the concept of mathematical creative thinking can make students despair and give up, so that another ability is needed so that students are able to survive and be able to change the difficulties encountered to become opportunities for themselves to advance. The ability possessed by a person in observing difficulties and cultivating these difficulties with intelligence possessed so that it becomes a challenge to be solved is known as Adversity Quotient (AQ). $A Q$ consists of 3 types, namely climber, camper, and quitter. This research is a qualitative descriptive study. This study intends to find out how the level of mathematical creative thinking ability in solving cubes and beams is reviewed from the Adversity Quotient type of Climber. The study was conducted in the even semester of the school year 2019/2020 in Ngamprah Middle School 2, class VIII which amounted to 31 students and the subjects in this study were 2 students. Data collection methods used in this study include: 1) tests used to determine students' abilities in mathematical creative thinking; 2) task-based interviews. The results showed that the climber students did the assimilation process of thinking at the stage of understanding the problem, preparing a settlement plan, solving the problem according to the plan, and re-examining the results that had been obtained and having the ability to work on creative thinking questions on the indicator of fluency, flexibility.
\end{abstract}

Keywords: Adversity Quotient climber; mathematical creative thinking; problem solving. 


\section{PENDAHULUAN}

Era revolusi 4.0 dan suasana persaingan yang semakin ketat menuntut manusia untuk berpikir kreatif, solutif dan menyeluruh, hal ini yang mempengaruhi tujuan pembelajaran di sekolah yang tertuang dalam kompetensi lulusan pada Kurikulum 2013. Dirumuskan dalam ranah psikomotor, yaitu peserta didik harus memiliki kemampuan pikir dan tindak yang efektif dan kreatif dalam ranah abstrak, dan konkret sesuai dengan yang dipelajari di sekolah dan sumber lain sejenis (Kemendikbud, 2013). Tujuan pembelajaran tersebut harus terimplementasi dalam setiap mata pelajaran yang diajarkan.

Kemampuan berpikir kreatif merupakan salah satu tujuan dalam pembelajaran matematika.

Proses berpikir kreatif yang dimaksud dalam pembelajaran matematika adalah siswa mampu menyelesaikan suatu persoalan matematika lebih menekankan proses menghasilkan solusi bervariasi yang bersifat baru dan unik. Hal ini sejalan dengan Livne (Muthahara, Kriswandani \& Prihatnani, 2018) bahwa kemampuan berpikir kreatif matematis merujuk pada kemampuan untuk menghasilkan solusi bervariasi yang bersifat baru terhadap masalah matematika yang bersifat terbuka.

Siswa akan terstimulus kemampuan berpikir kreatif matematis apabila diiringi oleh proses pembelajaran yang menunjang proses berpikir siswa terasah dan terarah. Peran guru untuk menciptakan dan mengembangkan materi ajar dan soalsoal yang bersifat terbuka. Beberapa pembelajaran matematika lebih cenderung memberikan soal-soal rutin pada buku teks yang hanya memiliki satu jawaban benar atau soal tertutup. menyatakan bahwa dalam pembelajaran matematika, guru memberikan soal-soal rutin yang hanya memiliki satu jawaban benar sesuai dengan buku teks. Selain itu, pembelajarannya lebih menekankan pada pemberian rumus dan penggunaan rumus secara langsung dalam menyelesaikan soal. Hal tersebut membuat siswa cenderung menghafal solusi masalah atau rumus jadi sesuai dengan yang dicontohkan oleh guru. Kecenderungan pembelajaran pembelajaran seperti ini juga masih terjadi dalam pembelajaran matematika di SMP Negeri 2 Ngamprah. Oleh karenanya, perlu dilakukan analisis kemampuan berpikir kreatif matematis yang dimiliki siswa guna mengetahui kemampuan berpikir kreatif matematis siswa.

Tiga indikator yang digunakan untuk menilai kemampuan berpikir kreatif adalah kefasihan (fluency), fleksibilitas (flexibility) dan kebaruan (novelty). Kefasihan (fluency) adalah jika siswa mampu menyelesaikan masalah matematika dengan beberapa alternatif jawaban (beragam) dan benar; fleksibilitas (flexibility) adalah jika siswa mampu menyelesaikan masalah matematika dengan dengan cara yang berbeda; kebaruan (novelty) adalah jika siswa mampu menyelesaikan masalah matematika dengan beberapa jawaban yang berbeda tetapi bernilai benar dan satu jawaban yang tidak biasa dilakukan oleh siswa pada tahap perkembangan mereka atau tingkat pengetahuannya.

Pengembangan konsep berpikir kreatif matematis dapat membuat siswa putus asa dan menyerah, sehingga dibutuhkan sebuah kemampuan lain agar siswa mampu bertahan dan mampu mengubah kesulitan-kesulitan yang ditemui menjadi peluang untuk dirinya lebih maju. Kemampuan yang dimiliki 
seseorang dalam mengamati kesulitan dan mengolah kesulitan tersebut dengan kecerdasan yang dimiliki sehingga menjadi sebuah tantangan untuk diselesaikan dikenal dengan Adversity Quotient (AQ) (Stoltz, 2000). Siswa yang memiliki Adversity Quotient (AQ) baik akan mampu bertahan menghadapi soal-soal yang rumit dan membutuhkan analisis yang ditemui selama pembelajaran di kelas maupun dalam soal-soal matematika, sebaliknya siswa dengan Adversity Quotient (AQ) rendah akan mudah stress dan menunjukkan sikap tidak antusias selama pembelajaran matematika serta mudah menyerah dan putus asa saat menyelesaikan soal-soal yang rumit.

Adversity Quotient (AQ) terbagi menjadi 3 bagian yaitu quitters, campers, dan climbers. Siswa yang memiliki tipe quitters mudah putus asa dan berhenti dalam pendakian. Siswa ini mudah menyerah, cenderung pasif dan memiliki motivasi yang rendah untuk menyelesaikan permasalahan. Siswa campers berusaha untuk menghadapi tantangan yang ada dan mencoba untuk menyelesaikan persoalan yang di hadapi. Usaha yang telah dilakukan oleh siswa tipe campers ini tidak mencapai puncak keberhasilan dan mudah puas dengan keberhasilan yang telah dicapainya. Mereka masih mengusahakan terpenuhinya kebutuhan rasa aman dan keamanan serta kebersamaan, serta masih bisa melihat dan merasakan tantangan. Siswa yang memiliki tipe climbers merupakan sekelompok siswa yang selalu berupaya mencapai puncak kesuksesan dan memiliki keinginan yang kuat untuk berusaha menyelesaikan persoalan yang dihadapi, siap menghadapi rintangan yang ada, dan selalu memotivasi dirinya agar tetap bersemangat mencapai impian dan keinginan. Climbers 4akan terus berusaha untuk menggapai kesuksesan tanpa menghiraukan latar belakang, keuntungan, atau kerugian, nasib buruk atau nasib baik.

Adversity quotient tipe climber memiliki kemampuan tangguh dalam menghadapi tantangan yang hadir kepadanya. Dia memiliki keyakinan yang besar terhadap sesuatu yang dianggap sulit untuk terwujud. Orang lain berpikir negatif terhadap sesuatu hal dan jalannya tidak mungkin untuk dapat terlaksana, orang tipe climber masih memiliki harapan besar dan berpikir positif akan sesuatu tersebut untuk terwujud dan terlaksana. Climber terbiasa dengan kondisi sulit dan penuh tantangan. Climber memahami kesulitan dan masalah harus dihadapi dan bagian dari kehidupan yang mesti di jalani.

Berdasarkan permasalahan
penelitian diatas maka dapat dirumuskan suatu penelitian tentang analisis kemampuan berpikir kreatif matematis siswa yang juga dapat digunakan untuk membantu guru dalam mengukur kemampuan siswa dalam menyelesaikan masalah matematika. Hal ini sejalan dengan penelitian Hidayat (2017) bahwa siswa SMA yang memiliki kemampuan AQ Climber memiliki kemampuan matematis yang baik dan pantang menyerah dalam menyelesaikan soal-soal matematika.

Orang yang ulet memanfaatkan peluang untuk menyelesaikan permasalahan. Suatu hal yang ingin dicapai memerlukan proses yang harus dijalani secara bertahap dalam memujudkannya. Climber memandang suatu kegagalan adalah Stoltz (2000) mengungkapkan bahwa dimensi tersebut antara lain fungsi control (kendali), origin dan ownership (asalusul dan pengakuan), reach (jangkauan) dan endurance (daya tahan). Makin 
besar nilai AQ, maka makin besar kecerdasannya dalam menghadapi kesulitan. Biasanya yang mempunya nilai tinggi, orang-orang yang berpengalaman atau pernah mengalami tingkat kesulitan yang tinggi tapi bisa bertahan hingga sukses. Stoltz (2004) mengemukakan bahwa rumus pengukuran Adversity Quotient seseorang adalah $\mathrm{C}+\mathrm{O} 2+\mathrm{R}+\mathrm{E}=\mathrm{AQ}$. Berdasarkan uraian di atas, maka maka indikator yang digunakan dalam penelitian ini mengadaptasi dari 4 dimensi tersebut yang diuraikan pada Tabel 1.

Tabel 1. Indikator Adversity Quotient

\begin{tabular}{lll}
\hline No & $\begin{array}{l}\text { Dimensi Adversity Quotient } \\
\text { (CO2RE) }\end{array}$ & Pengukuran Indikator \\
\hline 1 & $\begin{array}{l}\text { Control: kendali yang dirasakan } \\
\text { terhadap suatu peristiwa yang } \\
\text { menimbulkan kesulitan }\end{array}$ & $\begin{array}{l}\text { Kontrol diri pada saat merasakan adanya } \\
\text { kesulitan } \\
\text { origin dan ownership:siapa atau }\end{array}$ \\
$\begin{array}{l}\text { apa yang menjadi asal usul } \\
\text { kesulitan dan sejauhmana } \\
\text { seseorang mengakui akibat- } \\
\text { akibat kesulitan tersebut. }\end{array}$ & $\begin{array}{l}\text { Adanya pengakuan terjadinya kesulitan } \\
\text { Reach:sejauh manakah kesulitan } \\
\text { akan menjangkau bagian-bagian } \\
\text { lain dari kehidupan } \\
\text { Endurance: Daya Tahan }\end{array}$ & $\begin{array}{l}\text { Pengakuan siswa akan sejauh mana } \\
\text { kesulitan dianggap dapat menjangkau ke } \\
\text { bagian-bagian lain dari kehidupan } \\
\text { Mengenai berapa lama kesulitan dan } \\
\text { penyebabnya akan berlangsung }\end{array}$ \\
& &
\end{tabular}

Adapun tujuan dari penelitian ini adalah untuk mengetahui kemampuan berpikir kreatif matematis siswa pada materi bangun ruang sisi data di tinjau dari adversity quotient tipe climber.

\section{METODE PENELITIAN}

Penelitian ini merupakan

Penelitian ini bermaksud untuk mengetahui bagaimana tingkat kemampuan berpikir kreatif dalam menyelesaikan soal pemecahan masalah pada konsep balok dan kubus. Penelitian dilaksanakan pada semester genap tahun pelajaran 2018/2019 di SMP Negeri 2 Ngamprah, kelas VIII yang berjumlah 36 siswa dan subjek dalam penelitian ini adalah 2 siswa yang memiliki AQ dengan tipe climber.
Untuk mengetahui Adversity Quotient (AQ) dari masing-masing siswa maka diberikan angket AQ yang merujuk pada teori Paul G. Stoltz dengan melakukan perbaikan kalimat pada angket yang disesuaikan dengan tingkat berpikir siswa SMP.

Metode pengumpulan data yang digunakan dalam penelitian ini meliputi: 1) tes yang digunakan untuk mengetahui kemampuan siswa dalam berpikir kreatif matematis; 2) wawancara berbasis tugas. Uji kredibilitas data atau kepercayaan terhadap data hasil penelitian dilakukan dengan triangulasi waktu dan menggunakan bahan referensi. Wawancara berbasis tugas dilakukan untuk mengetahui proses berpikir siswa SMP tipe climber dalam menyelesaikan 
masalah matematika berindikator kemampuan berpikir kreatif.

Teknik analisis data yang digunakan adalah menggunakan konsep Miles dan Huberman, yaitu reduksi data, penyajian data, dan penarikan kesimpulan. (Sugiyono, 2011). Data dari hasil penelitian ini yaitu berupa hasil belajar siswa yang pengumpulan datanya menggunakan instrumen berupa soal kemampuan berindikator berpikir kreatif tes uraian sebanyak 4 soal dengan 3 indikator yaitu kefasihan (fluency), fleksibilitas (flexibility) dan kebaruan (novelty). Analisis data kualitatif pada penelitian ini, yaitu: 1) data reduction merupakan tahap merangkum dan memfokuskan data hasil analisis penelitian serta menghilangkan data yang tidak terpola, kemudian data-data di-kumpulkan dan dipilih sesuai dengan tujuan penelitian; 2) data display, data yang telah direduksi disajikan dalam bentuk uraian singkat sehingga mudah untuk dibaca dan dipahami baik secara keseluruhan maupun bagian-bagiannya; dan 3) conclusion drawing /verivication, kesimpulan diambil berdasar-kan hasil analisis dari semua data yang telah diperoleh.

\section{HASIL PENELITIAN DAN PEMBAHASAN}

Untuk mengelompokan siswa yang memiliki kemampuan Adversity Quotient adalah tes angket AQ. Tes angket AQ ini berdasarkan indikator yang sudah di susun sebelumnya. Hasil dari tes angket ini diperoleh beberapa siswa yang termasuk ke dalam AQ tipe Climber. Siswa S1 dan S2 merupakan siswa yang termasuk kelompok AQ tipe Climber. Berikut ini merupakan gambar hasil jawaban siswa terhadap soal kemampuan berpikir kreatif matematis untuk subjek dengan tipe Adversity Quotient (AQ) climbers.

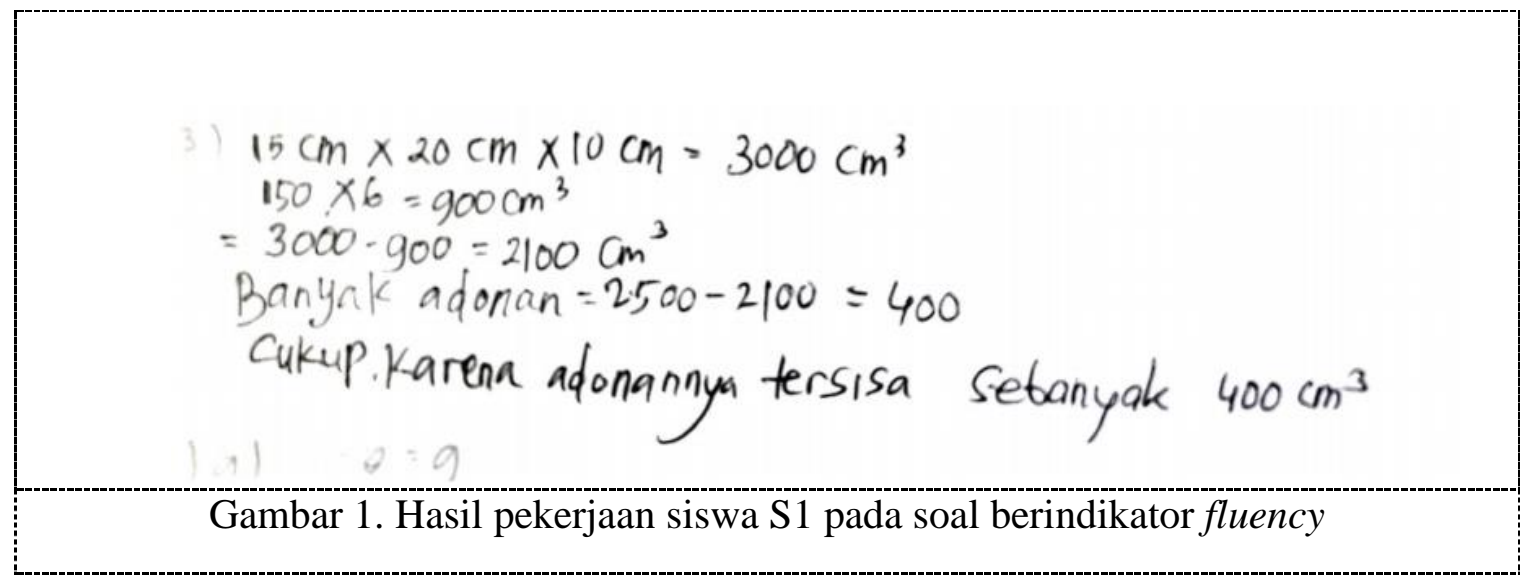


DOI: https://doi.org/10.24127/ajpm.v8i2.2118

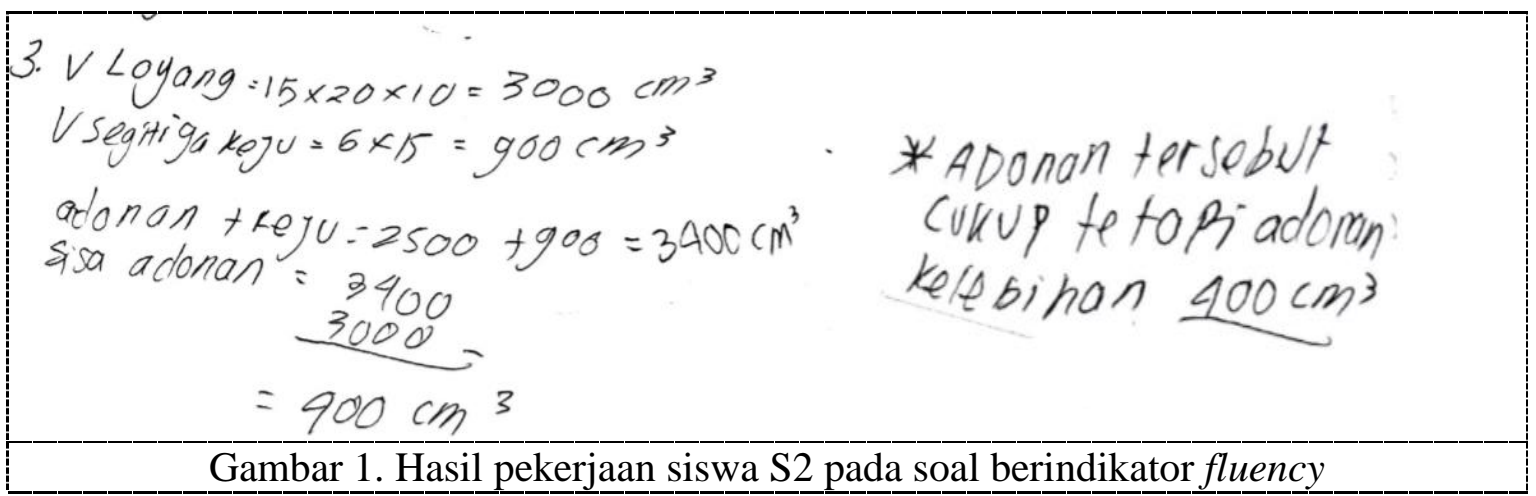
Subjek dengan tipe climbers
menyelesaikan masalah matematika, memiliki keyakinan yang tinggi bahwa setiap masalah pasti bisa terselesaikan, mereka tidak menyerah dan tidak berputus asa sesulit apa pun masalah yang sedang dihadapi sampai mereka mencapai kesuksesan atau mendapat jawaban yang benar. Meskipun soalnya sulit tetap berusaha untuk menyelesaikan sampai tuntas. Siswa S1 mampu menyelesaikan soal berindikator fluency. Terlihat pada Gambar 1 dan 2 di atas bahwa soal kemampuan berpikir kreatif berindikator fluency siswa S1 dan S2 mampu menyelesaikan secara benar. Perbedaan antara S1 dan S2 terlihat pada cara menyelesaikan soal. Siswa S1 merupakan siswa berjenis kelamin lakilaki dan siswa $\mathrm{S} 2$ berjenis kelamin perempuan. Sedangkan siswa S2 sudah sempurna melaksanakan tahap pemecahan masalah yaitu memahami masalah, menyusun rencana penyelesaian, menyelesaikan masalah sesuai perencanaan, dan memeriksa kembali hasil. Siswa S1 dan S2 memiliki kemampuan keinginan yang kuat untuk berusaha menyelesaikan soal yang di hadapi dan selalu memotivasi dirinya agar tetap bersemangat mencapai impian dan keinginan. Climbers akan terus berusaha untuk menggapai kesuksesan tanpa pantang menyerah.

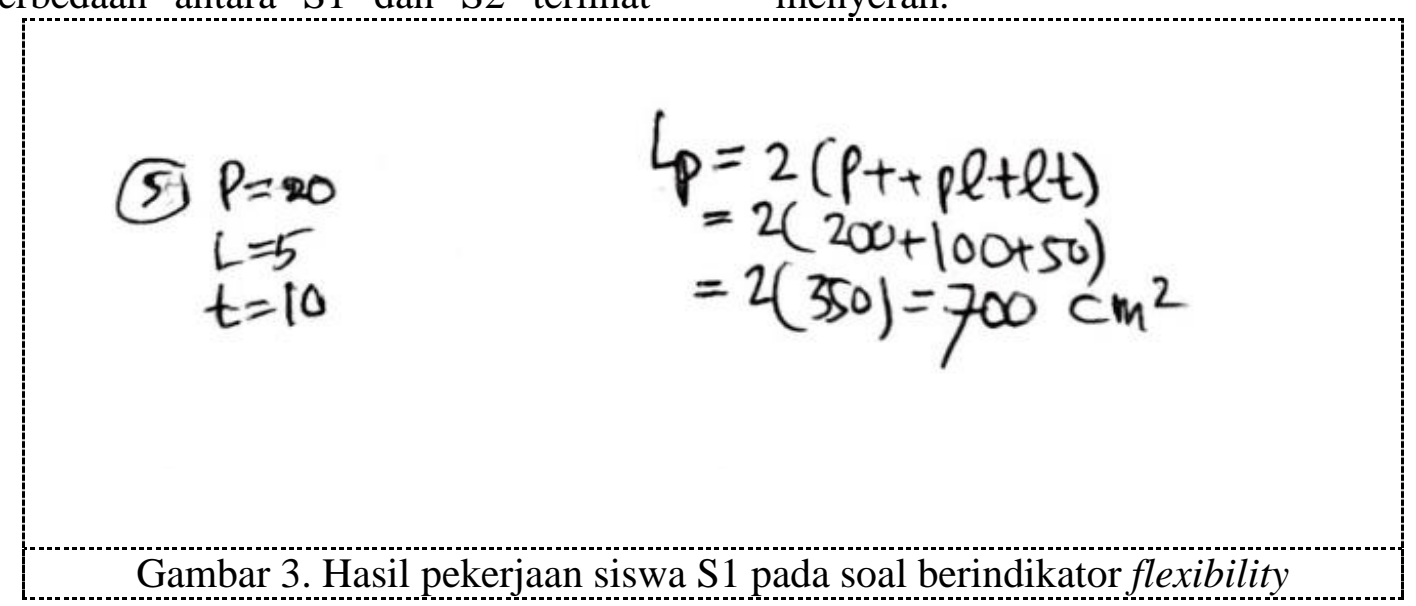


DOI: https://doi.org/10.24127/ajpm.v8i2.2118

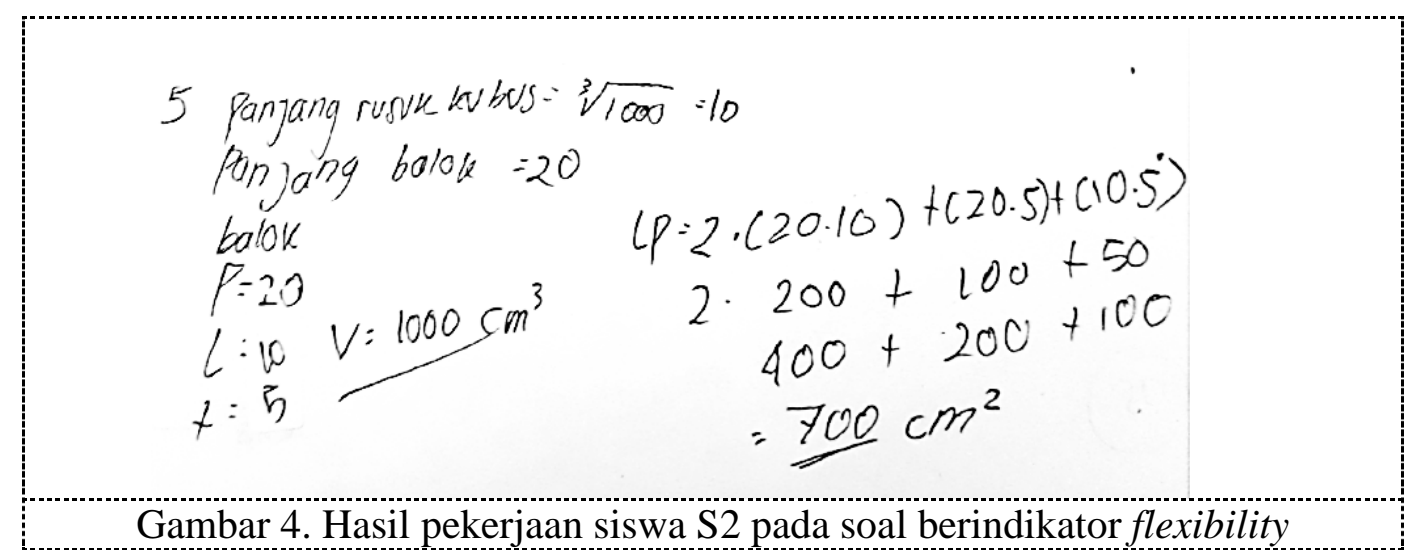

Gambar 3 dan 4 menunjukan hasil pekerjaan siswa $\mathrm{S} 1$ dan $\mathrm{S} 2$ soal kemampuan berpikir kreatif yang berindikator flexibility. Siswa S1 melewati tahap memahami masalah, tidak menuliskan komponen apa yang diketahui soal dan apa yang ditanyakan oleh soal. Siswa S1 tidak menuliskan satuan panjang. Siswa S1 untuk memperoleh nilai dari tinggi bangun ruang tersebut tidak menuliskan secara terperinci prosesnya. Siswa S1 menyelesaikan soal itu menggunakan cara yang sama sesuai yang disampaikan ole guru. Hal ini berarti, hasil pekerjaan S1 ini masih menggunakan satu cara bukan berbeda cara. SI dapat di katakana belum memiliki kemampuan flexibility. Siswa S1 sudah memiliki kemampuan untuk menyelesaikan soal tersebut berbeda cara dari yang telah disampaikan oleh guru. S1 menuliskan secara terperinci tahapan untuk memperoleh nilai tinggi bangun itu. S1 menuliskan satuan panjang, luas dan volume. S1 mampu memahami masalah, menyusun rencana penyelesaian, menyelesaikan masalah sesuai perencanaan, dan memeriksa kembali hasil. S1 memiliki kemampuan untuk memecahkan masalah matematis dengan baik. Selain itu, siswa S1 ini merupakan perempuan sehingga mempengaruhi cara berpikir dalam menyelesaikan suatu persoalan. Hal ini sejalan dengan penelitian Maharani, et. al (2019) yang menyatakan bahwa female students shows more detailed and communicative.It also shows that female students have more ability in students' verbal skills. Verbal ability is theability to displayvarious geometrical constructs by name, visualize geometry wake up according to its verbal description, specific geometry and its properties, formulate definitions correctly and correctly, express interwake relationships, recognize logical structures of oral problems, and formulate generalization statements and abstraction. Hal ini sejalan dengan stoltz (2004) bahawa siswa climber memiliki kemampuan daya tahan yang kuat dan pantang menyerah dalam menghadapi persoalan. S1 dapat dianggap sudah memiliki kemampuan berpikir kreatif yang berindikator flexibility. 


$$
\begin{aligned}
& \text { a } 2 \text { prisma yang terbentuk } 4 \text { buah } \\
& \text { b lya kongruen, Prisma Segitiga } \Rightarrow \text { Segitiga } \\
& \text { Prisma segiempat } \Rightarrow \text { Segiempat } \\
& \begin{aligned}
\text { c. Vprisma segltiga } & =1 \text { vas a las } \times \text { tinggl } \\
& =(\text { panjang } \times \text { lebar) } \times \text { tingyl } \\
& =8(\mathrm{~m} \times 6 \mathrm{~cm} \times 4 \mathrm{~cm} \\
& =48 \mathrm{~cm}^{2} \times 4 \mathrm{~cm} \\
& 192 \mathrm{~cm}^{3}
\end{aligned}
\end{aligned}
$$

Gambar 5. Hasil pekerjaan siswa S1 pada soal berindikator novelty

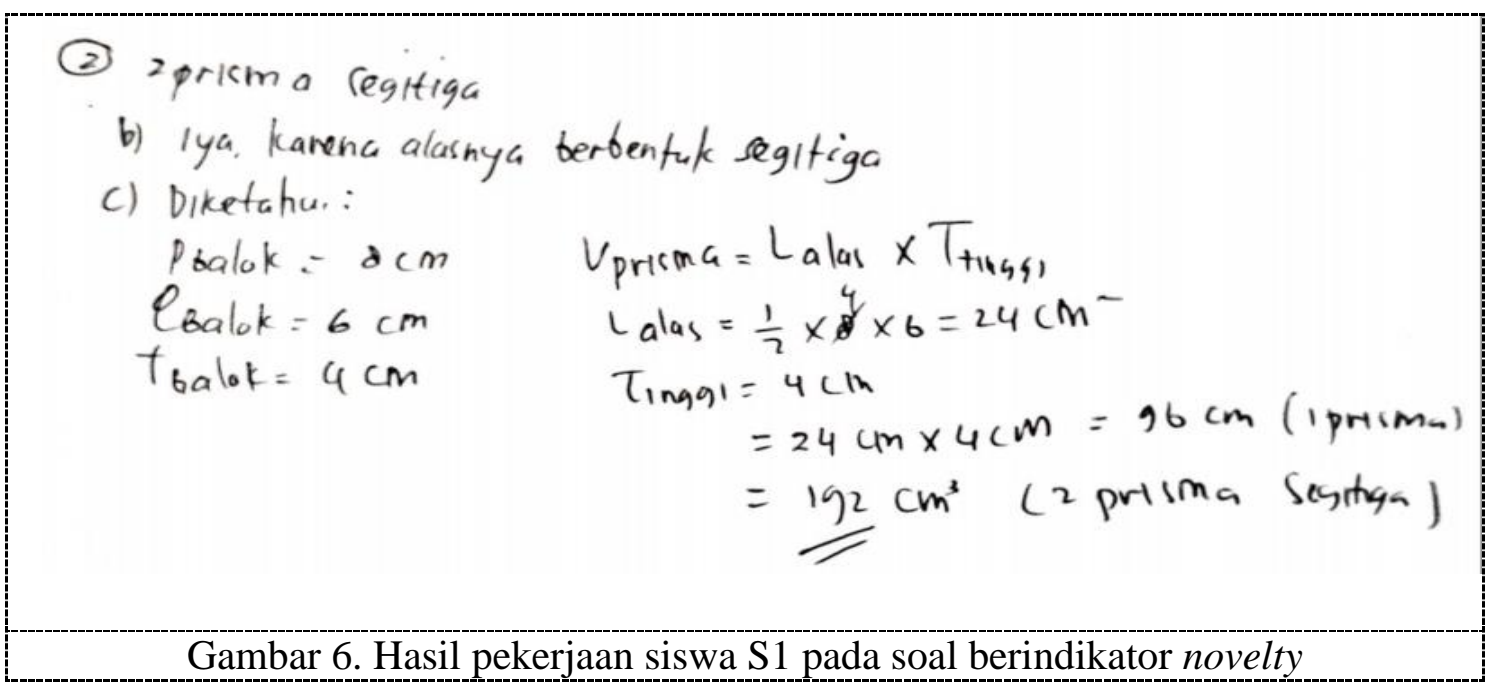

Pada Gambar 5 dan 6 terlihat siswa S1 menyelesaikan soal berpikir kreatif yang berindikator Novelty memahami secara baik langkah yang harus di tempuh yaitu menuliskan rumus untuk mencari volume prisma dan mampu memvisualisasikan jumlah prisma yang terbentuk. Demikian juga siswa S2 terlihat memamhi langkah yang harus dikerjakan dalam menyelesaiakan soal tersebut. Siswa S2 lebih lengkap menuliskan secara sistematis model matematis dari soal itu dibandingkan siswa S1. Siswa S1 dan S2 memberikan solusi yang unik dan berbeda satu sama lainnya. Mereka pun sudah memahami satuan volume yang harus dituliskan. Hasil jawaban siswa S1 dan S2 dapat di simpulkan bahwa ketercapaian kemampuan novelty belum secara baik.

Selain itu pada penelitian Rosania, Mujib \& Suri (2019) mengungkapkan bahwa perempuan lebih unggul dalam ketepatan, ketelitian, kecermatan, dan keseksamaan berpikir membuat siswa perempuan lebih unggul dalam menyelesaikan soal matematika terutama soal dengan indikator extended abstract dan relational. Karena dengan ketepatan, ketelitian, kecermatan, dan 
keseksamaan berpikir, jawaban dari penyelesaian soal lebih terperinci dan jelas. Dibandingkan siswa laki-laki yang kurang teliti dalam menyelesaikan soal, sehinggga banyak melakukan perhitungan yang salah. Penjelasaanpenjelasan diatas untuk tingkat kemampuan berpikir kreatif memiliki hal yang sejalan dengan penelitian yang dilakukan oleh Hidayat (2018) tentang ketercapaian kemampuan penalaran kreatif peserta didik yang menggunakan pembelajaran dengan Argument Driven Inquiry dengan tipe Climber tergolong ke dalam kategori tinggi tetapi peserta didik tersebut dikategorikan kurang baik penalaran kreatif karena dalam penyelesaiannya tidak memiliki cara yang berbeda dan baru atau unik (novelty). Dan hasil penelitian yang telah dilakukan oleh peneliti memiliki hal yang sejalan pula dengan penelitian yang dilakukan oleh Mulyaningsih \& Ratu (2018) mengenai level berpikir kreatif siswa bahwa penyelesaian sesuai apa yang dimaksud soal dengan memberikan jawaban benar dan alasan yang lengkap serta benar dengan menggunakan satu cara sehingga peserta didik tersebut dapat disimpulkan mampu memunculkan indikator kefasihan saja. Hasil wawancara siswa menyatakan bahwa soal yang diberikan dapat dikerjakan dan tingkat kesukaran soal tersebut sedang. Siswa memiliki perasaan tertantang untuk menyelesaikan soal kemampuan berpikir kreatif tersebut dan soal yang mereka kerjakan termasuk soal tidak rutin sehingga menstimulus siswa untuk berpikir dan menganalisis secara seksama.

\section{KESIMPULAN DAN SARAN}

Berdasarkan hasil analisis data penelitian dan pembahasan yang telah diuraikan, maka dapat ditarik kesimpulan bahwa kemampuan berpikir kreatif dalam menyelesaikan soal pemecahan masalah ditinjau dari adversity quotient tipe climber adalah siswa S1 dan S2 memiliki kemampuan fluency dan flexibility. Siswa S1 dan S2 dalam menyelesaikan soal berpikir kreatif tipe pemecahan masalah telah memenuhi tahapan memahami masalah, menyusun rencana penyelesaian, menyelesaikan masalah sesuai perencanaan, dan memeriksa kembali hasil. Siswa S1 dan S2 menyelesaikan soal berindikator novelty belum baik. Namun, langkah pemecahan masalah siswa S1 dan S2 sudah sesuai dan perhitungan aljabarnya sudah baik.

\section{DAFTAR PUSTAKA}

Hidayat, W.(2017). Adversity Quotient Dan Penalaran Kreatif Matematis Siswa SMA Dalam Pembelajaran Argument Driven Inquiry Pada Materi Turunan Fungsi. KALAMATIKA: Jurnal Pendidikan Matematika,2(1), 15-28.

Kemendikbud. (2013).Kerangka Dasar Kurikulum 2013. Kementerian Pendidikan dan Kebudayaan Direktorat Jenderal Pendidikan Dasar. Jakarta

Maharani, et. al (2019). Analyzing the student's cognitive abilities through the thinking levels of geometry van hiele reviewed from gender perspective No Title. In $J$. Phys.: Conf. Ser1188 012066 (pp. $1-8)$. 
DOI: https://doi.org/10.24127/ajpm.v8i2.2118

Mulyaningsih, T., \& Ratu, N. (2018). Analisis Kemampuan Berpikir Kreatif Siswa SMP dalam Memecahkan Masalah Matematika pada Materi Pola Barisan Bilangan. Jurnal Ilmiah Pendidikan Matematika, 3(1).

Muthaharah, Y.A. , Kriswandani.,\& Prihatnani, E.(2018).Analisis Kemampuan Berpikir Kreatif Matematis Siswa Smp Dalam Menyelesaikan Soal Bangun Ruang Sisi Datar. Jurnal Mitra Pendidikan, 2(1), 63-75.

Purwanti, D., Fakhri, J..\& Negara, H.S.(2019) Analisis Tingkat Kemampuan Berpikir Kreatif Matematis Peserta Didik Ditinjau Dari Gaya Belajar Kelas VII SMP. AKSIOMA: Jurnal Program Studi Pendidikan Matematika , 8(1),91102.

Purwasih, R .(2015). Peningkatan Kemampuan Pemahaman Matematis dan Self Confidence Siswa Mts di Kota Cimahi Melalui Model Pembelajaran Inkuiri Terbimbing.. Didaktik, 9 (1), 16-25.

Rosania, Y., Mujib., \& Suri, F.I. (2019). Pendekatan Teori Belajar Andragogi terhadap Kemampuan Menyelesaikan Soal Matematika ditinjau dari Gender . AKSIOMA: Jurnal Program Studi Pendidikan Matematika, 8(1),103-111.

Stoltz, P.G. (2000). Adversity Quotoient, Mengubah Hambatan Menjadi Peluang(diterjemahkan oleh $T$ Hermaya). Jakarta: PT Gramedia Widiasarana Indonesia.
Stoltz, P.G. (2004). Adversity Quotoient, Mengubah Hambatan Menjadi Peluang (kelima). Jakarta: PT Grasindo

Sugiyono. (2011). Metode Penelitian Pendidikan (Pendekatan Kuantitatif, Kualitatif, dan $R \& D$ ). Bandung: Alfabeta.

Yanti, A.P., \& Syazali, M. (2016). Analisis Proses Berpikir Siswa dalam Memecahkan Masalah Matematika Berdasarkan LangkahLangkah Bransford dan Stein Ditinjau dari Adversity Quotient. Al-Jabar: Jurnal Pendidikan Matematika,7(1), 63-74. 